\title{
A GLOBAL VIEW OF INDUSTRIAL LOGISTICS
}

\section{GESTÃO}

$\&$

\section{PRODUÇÃO}

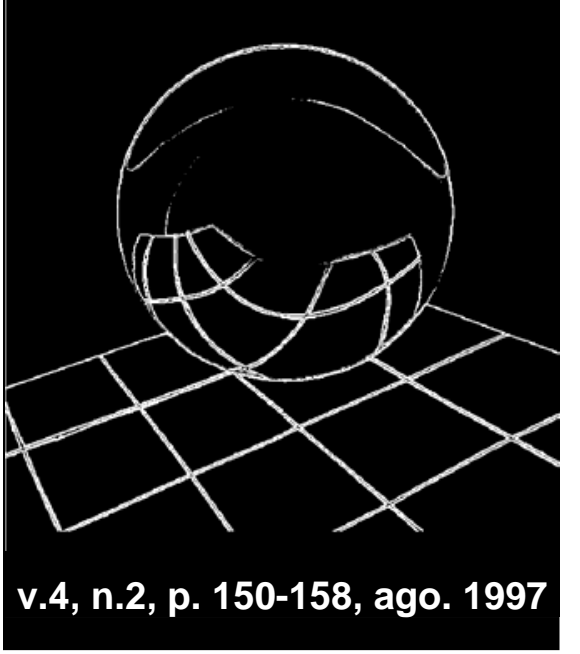

Lilian Barros, Ph. D.

Industrial Engineering Department Université de Technologie de Troyes

BP 8

10800 Saint Julien Les Villas - France tel: +33 325715625

fax: +33 325715649 email: barros2@univ-troyes.fr

\section{Abstract}

The term "industrial logistics" is a wide-reaching concept which incorporates various forms of supporting activities. In this paper, an attempt is made to provide a definition of the term which is broad enough to incorporate these various views. In a few words, there are three large categories of logistic support: (i) product support; (ii) production support, and (iii) industrial sector support. Although not new as a concept, there has been a recent surge of interest about industrial logistics, for good reasons. One of them might be that the absence of explicit integrated logistic considerations may explain the widening technological gap between the developed and developing worlds.

Key-words: industrial logistics, distribution, transportation, location, firm-level and sector-level logistics.

\section{Introduction}

I

n broad terms, current literature on industrial logistics can be classified under three headings: (i) product support, also referred to as engineering logistics or post-sale customer support, (ii) production support which includes more traditional forms of logistics such as the supply chain and final product distribution, and finally (iii) industrial sector which includes non-firm specific issues linked to transportation policy, support location of industrial parks, etc.

Starting with product support, engineering logistics is probably the narrowest and best defined concept, both in the literature and in practice: it incorporates 
after-sales support to highly technological (high-tech) equipment necessary to maintain a pre-defined level of system availability. The customer does nots buy hardware per se but the service it provides. The trade-offs between hardware quality and maintenance costs should be explicitly considered in hardware design. This is the case of Western Europe and USA military contractors as well as producers of durable consumer goods in general, particularly when producers intend to offer long-term maintenance contracts, as in the case of computers, photocopiers and airplanes manufacturers.

As far as production support is concerned, final product distribution is the best known aspect of industrial logistics which includes all services directly linked to the physical movement of goods from plant to customers via warehouses. Inventory control, warehouse location, vehicle routing and transportation are common issues included under this heading in textbooks for marketing, management science as well as logistics. Supply chain analysis has become rather popular in recent literature and practice (see, for instance, a recent paper of the pro-alcool program by YOSHIZAKI et al, 1996). The need to lower raw materials cost is often mentioned in international business literature as a reason for plant relocation, along with the notion of proximity to final product markets. The concept of logistic support to the industrial sector as a whole appears mainly in the regional development and international business literature. Regions and countries compete with each other for industrial investment by offering various advantages to incoming industry. These may be fiscal in nature, for instance, but the transportation and communication infrastructure play as fundamental a role as economic incentives such as preferential tax treatment, stable exchange rates, etc. which affect the evaluation of country risk. Other forms of foreign investment which do not require plant relocation such as non-equity participation (licensing, management contacts, etc.) do not require the same level of logistic support as foreign direct investment.

In other words, logistics support is necessary before the beginning of the production process (by supplying raw materials), during the production process (in-plant logistics, inventory control, etc...) and at the final end of the production process (final product distribution and postsale customer support). It also provides the infrastructure for the production process (transportation needs, intra-modal links, etc...).

\section{Firm Level Industrial Logistics}

$\mathrm{A}$ standard Webster dictionary defines logistics as "the procurement, maintenance and transportation of military material, facilities, and personnel”. The US Air Force includes the concept of engineering logistics explicitly by considering logistics as "the science of planning and carrying out the movement and maintenance of forces... (and aspects of military operations dealing with) design and development, acquisition, storage, movement, distribution, maintenance, evacuation, and disposition of material... personnel... facilities; and... services" (USAF, 1981).

A third classic definition of business logistics is provided in MAGEE (1968) as a system to manage the total flow of materials, from acquisition of raw materials to the delivery of finished products to ultimate users. The author lists the allencompassing definition of logistics proposed by the Society of Logistics Engineers as "the art and science of management, engineering, and technical 
activities concerned with the requirements, design, and supplying and maintaining resources to support objectives, plans and operations".

Another classic author, CHRISTOPHER (1987), proposes a definition of logistics similar to MAGEE's and asserts that productivity improvements in logistics could lower total corporate cost by 10 to 20 percent. Logisticians should be concerned with inventory control associated with service level and materials requirement planning, information needs associated with order processing and demand forecasting, warehousing and handling associated with depot location, unitisation and packaging, and finally transport issues such as mode decisions and scheduling. Production operations are clearly excluded from the "logistics mix". His most important contribution to a unified concept of logistics is the idea that "the whole purpose of logistics is to provide 'availability'. Everyone will be familiar with the old cliche: 'the right product in the right place at the right time'. If one adds 'at the least cost' then that is precisely the objective of logistics management” (p. 4)

RUSHTON \& OXLEY (1989) state in another classic logistics handbook that logistics and distribution are made up of several sub-functions which only recently have been regarded as a global function by academic and business specialists. The distribution function include but is not limited to physical distribution, logistics, materials management, product flow and supply chain management. A summary is offered in terms of an arithmetic equality:

materials management + distribution $=$ logistics .

In other words, logistics is concerned with physical and information flows from raw material to final distribution of the finished product. Several definitions tend to "show different biases: military, economic, dictionary, etc." but "distribution concerns the efficient transfer of goods from the place of manufacture to the place of consumption in a cost effective way whilst providing an acceptable service to the customer... The fundamental characteristics of a physical distribution structure are perhaps the flow of material of product, interspersed at various points by stationary intervals usually (used) for storage, or to allow some change to the product to take place-manufacture, assembly, packing, break bulk, etc.” (pp. 511). The particular functions attached to logistics/distribution include storage, warehousing and materials handling, transport, inventory, information and control (including forecasting), packaging and unitisation. In this instance, the terms logistics and distribution (including the supply of raw materials) are used interchangeably and have joint responsibility, among other things, for customer service level, forecasting and packaging (typically marketing roles) as well as systems support.

The main problem with all of these attempts at providing a global definition of logistics at the firm level is that the authors show the interconnection between logistics and other business function rather than attempt to define the logistics function. The logistician is generally defined as a cross between a marketing specialist, a systems analyst, a materials handling expert, a plant scheduler and a forecaster in charge of all inventory control, purchasing and distribution, if not corporate strategy in general and resource allocation. This highly interdisciplinary role requires very specialized 
training in most cases and certainly an enormous talent for corporate politics.

\subsection{Firm-Level Logistics: A Definition}

The integration of all the concepts discussed above does not pose insoluble problems. Product and production support tasks produce the following definition:

Industrial logistics at the firm level includes all the activities which allow the physical inflow and outflow of goods and associated services which link the firm to the external world before and after production takes place.

The logistical is therefore not responsible for demand forecasting or the determination of customer service level (marketing tasks), or materials handling within the plant (production tasks). His role is to assure the external links with the rest of the world outside the plant.

A graphic image makes the idea rather dear: if the entire set of logistics - production - marketing roles can be represented as a spider, the spider's body is production, the feet represent marketing and logistics is represented by the spider's legs or, even more precisely, by the flow going through its legs which keeps it alive. Evidently, if there is no production, there is no need for logistics, i.e. a spider without a body cannot survive with only legs. However, it will not function at its best if the body is not supported by the normal set of eight legs.

The concept can be tested against wellknown applications. The supply of raw materials from suppliers to plant and the supply of final product from plant to customers are logistic tasks. They link the firm to the out- side world and include physical movement of raw materials and final products in response to the demands of MRP and marketing. In administrative terms, it is probably more cost-effective to place raw materials inventories under the responsibility of the production department to assure a JIT view of logistics. Final goods inventory should be placed under the administrative responsibility the logistics (or distribution) department to assure quick delivery.

Product support or engineering logistics can be comfortably placed within the framework proposed: there is an implied notion of physical movement (of spares and labour) to maintain high-tech equipment in working order. The customer is willing to buy flight hours, photocopies of faster computational ability rather than airplanes, photocopiers or personal computers. In that sense, engineering logistics keeps delivering to the client the intended final product which is really the service derived from a well-functioning piece of equipment rather than the physical output of the production process.

Military logistics also fits within the definition: it transports supporting items which make the "production of war" feasible and as cost-effective as possible. The only difference is that the "product" (war) is instantaneously delivered to "customers" (opposing forces). Casualties can be considered as a by-product of the production process which must be delivered to appropriate "repair units" (health care centres).

\section{Sector - Level Industrial Logistics}

I nternational business location issues form an important sub-class of sectorlevel logistic problems although ROBOCK \& SIMMONDS (1989) point out that "the global planning approach is basically the same for either domestic or international expansion, except that a new range of variables and risks resulting from crossing national boundaries must be included in the decisions-making process” 
(p.58). The authors propose a rational global planning model or a geobusiness theory of international adjustment of the firm where the firm will develop logistic models working back from its market objectives and following location economic criteria in order to define rational patterns for supplying selected markets.

Countries compete as alternative sites offering packages which may include "soft" logistic support facilities which are leading to a "dramatic internationalization of banks - both commercial and investment - and of securities firms. ... U.S. commercial banks led the international banking movement... (by following) their domestic customers overseas to service better their clients international operations" (p.90). In addition to the competition for manufacturing plants, there is interest in original equipment manufacturing arrangements (OEM). The UN Centre of Transnational Corporations (1988) presented a list of such contracts in the mid-1980s between developing country enterprises and major multinationals which included products of a very high level of technological sophistication, particularly in Korea and Taiwan. The main requirements are the availability of producers with the necessary technical or managerial capacity but also the reliability in meeting deadlines and quality standards.

Highly specialized technological poles have developed in France (in Nice and Grenoble, for example) and the USA (the Silicone Valley in California). In Brazil, military investments in research and development have opened the way to spatially concentrated commercial investment in avionics and other high-tech industry. The role of governments in directing technological development ("targeting") is often mentioned in the economic development literature to compare recent growth patterns observed in Latin-America and south-east Asia. The infrastructure provided in the case of the latter included "soft" logistics in the form of an effective institutional infrastructure as well as good transport and communication facilities (see, for instance, SCHWARTZ (1991).

Furthermore, logistics is inserted within the production process when components are exported from a free-tax zone to another country, processed at a lower cost, reimported and reintroduced into the production process. A good example is provided by the "maquiladora" industry in Mexico which supports some of the most modern industrial processes in the USA through a network of about 1000 twin-plants or in-bond manufacturing which employ about 310,000 people (CASTEL, 1993). Imports of raw materials, components and machinery are free of import tax, provided most of the output is exported back to the USA for further processing or final distribution where import tarifs are levied on the (lower) Mexican value added. Examples of products assembled in "maquilas" include computer keyboards, waterbeds, carburetors, toys, extension cords, refrigerators and television sets.

\subsection{Sector-Level Logistics: A Definition}

In the sector-level view of logistics, there is no significant difference between purchasing and distribution: input suppliers to some production process are output distributors to the immediately preceding stage of industrial (or agricultural) production of raw materials, as in an input-output matrix. A similar definition to the one proposed at the firm level will have wider economic implications:

Industrial logistics at the sector level include all activities which allow the physical flow of raw materials, intermediate and final goods and associated 
services from suppliers to industrial producers to consumers within and across economic sectors thus allowing industrial production to take place in a spatially concentrated or dispersed manner.

In this case, an individual firm is a microscopic link between suppliers and customers, the industrial sector being a component of a double-entry input-output matrix. The physical movement of raw materials from domestic or international sources feeds the industrial sector (and various forms of intermediate consumption) and moves on to consumers under the form of final products. This movement is supported by transportation and telecommunications networks as well as financial, legal and other informationintensive forms of services. Maintaining the image of the spider and its legs, the sectorlevel logistics can be represented by the ground where the spider stands and by the fact that each spider is connected to two other spiders by its feet (to the left and the right of its body). In other words, the ground represents a location decision and the feet links an industrial input-output matrix.
The two definitions reveal a similar logical structure but the implications are rather different for logistics specialists: in both cases, the expert is concerned with physical movement of materials, goods and services with an origin or destination which are external to the firm or industrial sector. However, the individual firm's supply and distribution needs are met by a logistics specialist who to responds to production schedulers and marketing forecasts.

The sector-level logistician is concerned with global networks which make the external links work as efficiently and cost-effectively as possible. Transportation, communication and information-intensive networks are particularly critical when technological parks, regions or countries are competing for industrial direct investment. This specialist is interested in plant location issues (particularly in the case of foreign investment) and in regional or sectoral planning issues. National planning issues which affect the free flow of goods and services in the industrial sector also concern this specialist.

\section{Modelling Industrial Logistics}

field with such a broad scope will
require an equally broad spectrum
of modelling techniques to solve typical problems. An early predecessor, GEISLER (1975), edited a series of quantitative case studies applied to transportation routing, production planning and scheduling, simulation, optimum level of repair analysis, dynamic pricing of resources, dispatching in an assembly shop, storage systems and finally the economics of staffing and scheduling in a dental practice.

Product support models dealing with reliability and equipment replacement problems are included in recent publications such as KALVELAGEN \& TIJMS (1990).
Models which estimate life-cycle costs or the costs of ownership tend to appear in engineering logistics textbooks, often using techniques as elementary as present value analysis, as in BLANCHARD (1982) or more sophisticated modeling, as the simulation model applied to computing equipment replacement discussed in NAYLOR (1981). Reliability prediction models tend to be mathematically more elegant by using probability theory, Markov chains and neural networks (see, for instance, the proceeding of the 1997 meeting of the European Safety and Reliability Association in Lisbon).

Some aspects of industrial logistics applied to production support such as transportation 
and transhipment models are included in OR textbooks such as ANDERSON et al (1991) as applications of techniques such as network analysis, linear programming or special-purpose algorithms. In terms of industrial sector support, warehouse and plant location models are common topics in the social sciences, as demonstrated in a classic textbook by BURGHES \& WOOD (1985). In recent years, public sector planning has been in great disfavor and therefore there is little published on technological parks which is not simply qualitative observations associated with trends observed.

A 1993 TIMS/ORSA (now INFORMS) conference on transportation and logistics showed that among the 200 logistics papers, $49 \%$ used networks, $13 \%$ heuristics and 10 $\%$ linear programming. As far as areas of application, distribution problems were discussed in $45 \%$ of the papers, followed by transportation issues (38\%).

Table I summarises these observations, using the conference proceedings as source.

Table I - Methods used in modelling logistics

\begin{tabular}{|c|c|c|c|c|c|c|}
\hline METHOD & $\begin{array}{l}\text { ENG. } \\
\text { LOG. }\end{array}$ & MILITARY & $\begin{array}{c}\text { DISTRIBU- } \\
\text { TION }\end{array}$ & $\begin{array}{c}\text { TRANS- } \\
\text { PORTATION }\end{array}$ & TOTAL & $\%$ \\
\hline $\begin{array}{l}\text { Mathematical } \\
\text { programming }\end{array}$ & - & 3 & 6 & 12 & 21 & $11 \%$ \\
\hline Networks & 2 & 1 & 77 & 17 & 97 & $49 \%$ \\
\hline Simulation & - & 4 & 2 & 10 & 16 & $8 \%$ \\
\hline Heuristics & 2 & 4 & - & 20 & 26 & $13 \%$ \\
\hline Statistics & 4 & 2 & 3 & 10 & 19 & $10 \%$ \\
\hline $\begin{array}{l}\text { Management } \\
\text { Operations }\end{array}$ & 6 & 7 & 1 & 7 & 21 & $11 \%$ \\
\hline $\begin{array}{l}\text { TOTAL } \\
\%\end{array}$ & $\begin{array}{l}14 \\
7 \%\end{array}$ & $\begin{array}{l}21 \\
11 \%\end{array}$ & $\begin{array}{l}89 \\
45 \%\end{array}$ & $\begin{array}{l}76 \\
38 \%\end{array}$ & $\begin{array}{l}200 \\
100 \%\end{array}$ & $\begin{array}{c}100 \\
-\end{array}$ \\
\hline
\end{tabular}

Source: TIMS/ORSA Joint National Meeting Proceedings (May 1993)

It should be noted that there is an international network of modellers in all fields of logistics which have met regularly every two years since 1993 to discuss their research. The network called "International Conference on Industrial Logistics” (ICIL) has met in Rennes, France (ICIL'93), in Ouro Preto, Brazil (ICIL'95) and it will meet in Chico, California (ICIL'97). The ICIL structure relies on the broad definition proposed in this paper and classifies the sessions under the main leadings of: (i) product support logistics; (ii) production support logistics and (iii) industrial sector logistics.

\section{Industrial Logistics and Development}

$\mathrm{t}$ the firm level, the advantages of
an integrated view of logistics are
well know: lower inventory costs at both ends of the production process and better service to industrial clients and final consumers without a corresponding increase in transportation costs. This is particularly important given recent steep rises in 
logistics costs: transportation and storage costs in the UK have increased 50 and 70 percent, respectively, in the last decade. A USA survey showed that transportation accounted for 46 percent of distribution costs, followed by inventory storage and carrying costs (44 percent), the remainder being consumed by administration.

Better service to clients include aftersales technical support by logistics engineers as operating and maintenance costs may account for as much as 50 percent of total system life cycle costs which include initial acquisition costs.

At the industrial sector level, an integrated view of supply and distribution functions will define important coordinates for plant and warehouse location decisions, taking into account domestic and international links. These considerations already play a critical role when multinational corporations consider alternative location sites: for instance, investment flows into Japan during the 1980's world crisis were relatively low partly due to a complicated distribution structure. At the same time, investment levels to eight major recipients in South East Asia remained relatively high due to large domestic markets (China, Indonesia and Thailand), a well developed supporting structure for production and exports (Hong Kong, Malaysia, Singapore and Taiwan) as well as low cost of skilled labour and the availability of natural resources (Indonesia and Malaysia).

In Latin-American, the flow of foreign direct investment dropped sharply during the same period but the last few decades have shown a serious concern with logistics support to the industrial sector. There have been recent studies on road and rail transport in Colombia, and research on industrial relocation in Brazil, for instance. Although the Brazilian industry is spreading somewhat, it is still highly concentrated in the State of Sao Paulo probably because the industrial infrastructure is substantially better than elsewhere in the country.

Large flows of foreign industrial investment towards the III World is having serious economic impact in the I World. Industrial production may double in the next 15 to 20 years with a corresponding decline in employment of 25 to 40 percent due to a general process of automation observed even in traditional industrial sectors. These developments and organizational changes are emphasizing low or zero inventories, customized production and high quality, all of which require suppliers to be in close proximity to customers or user, thus lowering the growth in investments for export back to the I World.

On the other hand, developed economies are integrating domestic informationintensive services such as banking, finance, insurance and business services, a process which has almost by-passed the developing countries. Advanced technology which includes an integrated approach to industrial logistics and "soft" logistics are providing clear comparative advantages to developed countries and a few newly industrialized countries. Precise estimates of the economic benefits arising from these new forms of industrial organization are not easily available but they are likely to be significant and rising over time.

\section{References:}

ANDERSON, D.R.; SWEENEY, D.J. \& WILLIAMS, T.A.: An Introduction to Management Science. West Publishing Company, St. Paul, 1991.
BLANCHARD, B.S.: Logistics Engineering and Management. Prentice-Hall, Inc., New Jersey, 1986. 
BURGHES, D.N. \& WOOD, A.D.: Mathematical Models in the Social, Management and Life Sciences, John Wiley \& Sons, Chichester, 1985.

CASTEL, O.: “L'Industrie'maquiladora' au Mexique: une organisation en réseau”. Proceedings of the International Conference on Industrial Logistics. July 1993, Rennes, France.

CHRISTOPHER, M.: Effective Logistics Management. GowerPublishing Co., Cambridge, 1987.

GEISLER, M.A.: (ed.). Logistics. North-Holland Publishing Co., New York, 1975.

KALVELAGEN, E. \& TIJMS, H.C.: Exploring Operations Research \& Statistics in the Micro Lab. Prentice-Hasll International Inc., Englewoods Cliffs, 1990.

MAGEE, J.F.: Industrial Logistics. McGraw-Hill Book Company, New York, 1968.

NAYLOR, T.H.: (ed). Simulation in Business Planning and Decision Making. Simulation Councils, Inc., La Jolla, 1981.
ROBOCK, S.H. \& SIMMONDS, K.: International Business and Multinational Enterprises. Richard D. Irwin, Inc., Boston, 1989.

RUSHTON, A. \& OXLEY, J.: Handbook of Logistics and Distribution Management. Kogan Page Ltd., London, 1989.

SCHWARTZ, H.H.: Supply and Marketing Constraints on Latin American Manufacturing Exports. Johns Hopkins University Press, Washington, D.C. 1991.

United Nations Centre on Transnational Corporations. "Transnational Corporations in World Development”. Trends and Prospects. United Nations, New York, 1988.

USAF Institute of Technology. "Compendium of Authenticated Systems and Logistics Terms, Definitions and Acronyms". AU-AFIT-LS-3-81, Wright-Patterson AFB, April 1981.

YOSHIZAKI, H.T.; MUSCAT, A.R.N. \& BIAZZI, J.L.: "Decentralizing Ethanol Distribution in Southeastern Brazil”, Interfaces (26:6), 1997, pp. 24-34.

\section{UMA VISÃO GLOBAL DA LOGÍSTICA INDUSTRIAL}

\section{Resumo}

O termo "logística industrial” é um conceito amplo que incorpora várias formas de atividades de suporte. Neste artigo, uma tentativa é feita para fornecer uma definição deste termo, ampla o suficiente para incorporar estas várias visões. Resumidamente, existem três grandes categorias de atividades de suporte logístico: (i) suporte de produto; (ii) suporte de produção, e (iii) suporte do setor industrial. Embora não seja um conceito novo, tem havido um surto recente de interesse em logística industrial, por boas razões. Uma delas poderia ser que a falta de considerações explícitas de logística integrada devem explicar a ampla defasagem tecnológica entre mundos desenvolvidos e em desenvolvimento.

Palavras-chave: logística industrial, distribuição, transporte, localização, logística em nível de firma e de setor. 